\title{
Synthesis and Characterization of ZnO Thin Film for Modeling the Effect of Its Defects on $\mathrm{ZnO} / \mathrm{Cu}_{2} \mathrm{O}$ Solar Cell EQE
}

\author{
S. Chala ${ }^{1,2, *}$, R. Boumaraf ${ }^{1}$, A.F. Bouhdjar ${ }^{1}$, M. Bdirina ${ }^{3}$, M. Labed ${ }^{1,4}$, T.E. Taouririt ${ }^{1}$, M. Elbar ${ }^{1}$,
} N. Sengouga ${ }^{1}$, F. Yakuphanoğlu ${ }^{5}$, S. Rahmane ${ }^{3}$, Y. Naoui ${ }^{6}$, Y. Benbouzid ${ }^{7}$

${ }^{1}$ Laboratory of Metallic and Semiconducting Materials, Mohamed Khider University, 07000 Biskra, Algeria

2 Institute of Electrical and Electronic Engineering, M'Hamed Bougara University, 35000 Boumerdes, Algeria

${ }^{3}$ Laboratory of Physics of Thin Films and Applications, Mohamed Khider University, O7000 Biskra, Algeria

${ }^{4}$ Graduate School of Food Sciences and Food Industries, 16200 Algiers, Algeria

${ }_{5}^{5}$ Physics Department, Firat University, 23169 Elazig, Turkey

${ }^{6}$ Physics Department, Constantine 1 University, 25017 Constantine, Algeria

7 Physics Department, Ziane Achour University, 17000 Djelfa, Algeria

(Received 28 November 2020; revised manuscript received 15 February 2021; published online 25 February 2021)

\begin{abstract}
Zinc oxide $(\mathrm{ZnO})$ is one of the best transparent conducting oxide (TCO) materials with a wide bandgap and good electrical and optical properties. Its low cost, nontoxicity and transparency in the optical region of the electromagnetic spectrum make it very promising candidate for solar cell applications. In this work, zinc acetate precursor was used to grow a $\mathrm{ZnO}$ thin film by using sol-gel spin-coating technique. The surface morphological study using scanning electron microscope (SEM) was carried out to confirm the growth pattern and crystal distribution. The optical properties, transmission $(T)$, reflection $(R)$, optical bandgap $\left(E_{g}\right)$, refractive index $(n)$, and extinction coefficient $(k)$ were extracted and investigated to be used in the simulation of $\mathrm{ZnO} / \mathrm{Cu}_{2} \mathrm{O}$ heterostructure solar cell, where $\mathrm{ZnO}$ thin film plays a double role: as the TCO window, as well as the emitter of the $n-p$ junction. However, the solar cell showed weak external quantum efficiency (EQE) compared to those prepared by using zinc nitrate and diethyl zinc precursors. TCAD numerical simulation was used to clarify the origin of this weak EQE by taking into account two parameters. The first studied parameter is the root-mean-square interface roughness, $\sigma_{R M S}$, in Haze modeling approach, $H$, which describes how much of incident light is scattered at the interface. The second studied parameter is the density of defects in the $\mathrm{ZnO}$ bulk with continuous distribution of states in its bandgap similar to an amorphous semiconductor made of tail bands and Gaussian distribution deep level bands. Consequently, and by adjusting and investigating the effect of the $\sigma_{R M S}$ and the constituents of the bandgap states, we were able to obtain a good agreement between simulated and measured EQE characteristics of the solar cell.
\end{abstract}

Keywords: Sol-gel, EQE, Defects, Simulation, $\mathrm{ZnO} / \mathrm{Cu}_{2} \mathrm{O}$ Solar Cell.

DOI: 10.21272/jnep.13(1).01009

\section{INTRODUCTION}

II-VI thin films such as $\mathrm{ZnO}, \mathrm{CdO}, \mathrm{ZnS}, \mathrm{CdS}$ and CdTe are used for many optoelectronic applications such as transparent conducting oxides (TCOs) and window layers in photodiodes and solar cells [1-6]. $\mathrm{ZnO}$ is one of the II-VI promising material which has been studied in recent years due to its unique properties such as wide-band gap and high transparency [6]. It is an n-type semiconductor without doping and is widely studied because of their low fabrication cost, nontoxicity, and its abundance on earth.

Cuprous oxide $\left(\mathrm{Cu}_{2} \mathrm{O}\right)$ is a direct-bandgap semiconductor with a bandgap $\left(E_{g}\right)$ of about $2.1 \mathrm{eV}$. This material usually shows $p$-type conductivity without intentional doping [7]. The optical absorption coefficients of this material are above $10^{4} \mathrm{~cm}^{-1}$ near the band edge [8]. In addition, $\mathrm{Cu}_{2} \mathrm{O}$ can be prepared by low-cost methods such as oxidation of $\mathrm{Cu}$ sheets, [9], and electrodeposition from aqueous solutions of copper sulfate and lactic acid [10-12]. These features indicate that $\mathrm{Cu}_{2} \mathrm{O}$ is a promising material for an absorber layer of thin-film solar cells, and $\mathrm{Cu}_{2} \mathrm{O}$ heterojunction solar cells using $\mathrm{ZnO}$ emitter layer [13].

Firstly, we prepare a $\mathrm{ZnO}$ thin film by sol-gel spincoating technique then extract the optical parameters
PACS numbers: 78.20.Bh, 73.40.Lq, 84.60.Jt

to be used in modeling the $\mathrm{ZnO} / \mathrm{Cu}_{2} \mathrm{O}$ heterojunction solar cell. The sol-gel delivered $\mathrm{ZnO} / \mathrm{Cu}_{2} \mathrm{O}$ solar cell which was fabricated by zinc acetate precursor shows a weak EQE [1]. In this work, TCAD numerical simulation was used to model the solar cell and to explain its weak EQE.

\section{EXPERIMENTAL DETAILS}

$\mathrm{ZnO}$ thin film was developed by sol-gel spin coating method. Before forming a $\mathrm{ZnO}$ layers on the glass substrate, the native oxide on the front surface of the substrate was removed in HF solution, then, the wafer was rinsed in DI water. To obtain the sol, the precursor Zinc acetate dehydrate was first dissolved into 2-methoxyethanol as a solvent and by adding a stabilizer. The molar ratio to zinc acetate was maintained at 1:1 and the concentration of zinc acetate was $0.6 \mathrm{M}$. After stirring for $1 \mathrm{~h}$, a homogeneous solution was obtained. The substrate was placed on the sample holder and was rotated at a speed of $3000 \mathrm{rpm}$ for $30 \mathrm{~s}$. After each spin coating the substrate was dried in a furnace at $300{ }^{\circ} \mathrm{C}$ for $10 \mathrm{~min}$ to evaporate the solvents. After this process was repeated 10 times, thermal treatment was carried out at $450^{\circ} \mathrm{C}$ for $1 \mathrm{~h}$ to decompose completely the organic component from the film.

\footnotetext{
*chala_slimane@yahoo.com
} 


\section{DEVICE SIMULATION}

Atlas TCAD software was used in this study. It is a physically-based two and three dimensional device simulator. It predicts the electrical behavior of a specified structure and the internal physical mechanisms involved. It solves a set of fundamental equations, which link together the electrostatic potential and the carrier densities, through Poisson's equation, the carrier continuity equations and the transport equations [14].

The structure and band diagram of the modeled solar cell device are shown in Fig. 1.

The parameters of each material used to simulate the ideal $\mathrm{ZnO} / \mathrm{Cu}_{2} \mathrm{O}$ solar cell are presented in Table 1 .

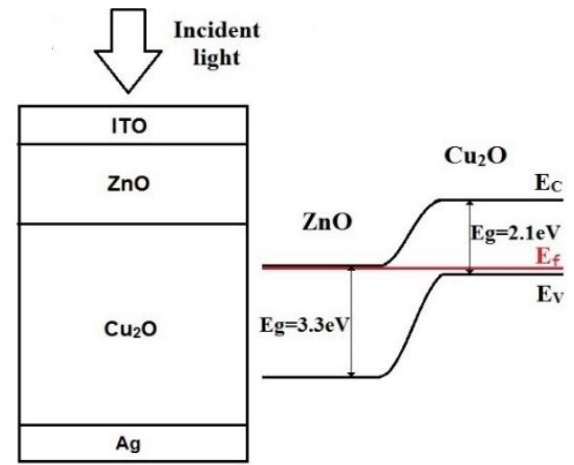

Fig. 1 - The structure and band diagram of the $\mathrm{ZnO} / \mathrm{Cu}_{2} \mathrm{O}$ solar cell device. $E_{C}, E_{V}$ and $E_{F}$ are the minimum conduction band energy, maximum valence band energy and Fermi level, respectively

Table 1 - The parameters of each material used to simulate the ideal $\mathrm{ZnO} / \mathrm{Cu}_{2} \mathrm{O}$ solar cell

\begin{tabular}{|l|l|l|}
\hline Parameter & $\mathrm{ZnO}$ & $\mathrm{Cu}_{2} \mathrm{O}$ \\
\hline Thickness & $0.5 \mu \mathrm{m} \mathrm{[1]}$ & $2.7 \mu \mathrm{m}[1]$ \\
\hline Bandgap & $\begin{array}{l}E_{g}=3.305 \mathrm{eV} \\
{[\text { Extracted] }}\end{array}$ & $2.1 \mathrm{eV}[9]$ \\
\hline Electron affinity & $4.5 \mathrm{eV}[14]$ & $3.2 \mathrm{eV}[15]$ \\
\hline $\begin{array}{l}\text { Donor concentra- } \\
\text { tion, ND }\end{array}$ & $1 \times 10^{19} \mathrm{~cm}^{-3}[14]$ & 0 \\
\hline $\begin{array}{l}\text { Acceptor concentra- } \\
\text { tion, NA }\end{array}$ & 0 & $5 \times 10^{15} \mathrm{~cm}^{-3}[16]$ \\
\hline $\begin{array}{l}\text { CB effective density } \\
\text { of states, NC }\end{array}$ & $2.2 \times 10^{18} \mathrm{~cm}^{-3}$ & $2.43 \times 10^{19} \mathrm{~cm}^{-3}[15]$ \\
\hline $\begin{array}{l}\text { VB effective density } \\
\text { of states, NV }\end{array}$ & $\begin{array}{l}1.8 \times 10^{19} \mathrm{~cm}^{-3} \\
{[14]}\end{array}$ & $1.34 \times 10^{19} \mathrm{~cm}^{-3}[15]$ \\
\hline Electron mobility & $100 \mathrm{~cm}^{2} / \mathrm{Vs}[14]$ & $100 \mathrm{~cm}^{2} / \mathrm{Vs}^{[14]}$ \\
\hline Hole mobility & $25 \mathrm{~cm}^{2} / \mathrm{Vs}[14]$ & $61 \mathrm{~cm}^{2} / \mathrm{Vs} \mathrm{[17]}$ \\
\hline
\end{tabular}

\section{$3.1 \mathrm{ZnO} / \mathrm{Cu}_{2} \mathrm{O}$ Interface}

In the simulator direct, non-scattered, light is analyzed in terms of coherent electromagnetic waves, whereas for scattered light tracing of incoherent rays is used. The main input parameters of the simulator are: the number of layers in the structure, layer thicknesses, wavelength-dependent complex refractive indexes for each layer, root-mean-square interface roughness, oRMs, illumination spectrum and others.

Among them, realistic scattering parameters are most difficult to be determined. In our study, we use Haze, $H$, modelling approach which describes how much of incident light is scattered at an interface and it has to be defined for reflected and transmitted light at a rough interface. In general, this parameter is dependent on the morphology of the rough interface and optical properties of the media (layers) forming the interface and the type of incident light. Experimentally, $H$ parameter can be determined only outside the solar cell. In simulation, it can be determined for internal interfaces following calibrated equations of scalar scattering theory, $[18,19]$, by using reflected, $H_{R}$, and transmitted light, $H_{T}$, at a rough interface in the solar cell

$$
\begin{gathered}
H_{R}=1-\exp \left[-\left(\frac{4 \pi \sigma_{R M S} C_{R} n_{1} \cos f_{1}}{\lambda}\right) N_{R}\right] \\
H_{T}=1-\exp \left[-\left(\frac{4 \pi \sigma_{R M S} C_{T}\left|n_{1} \cos \varphi_{1}-n_{2} \cos \varphi_{2}\right|}{\lambda}\right) N_{T}\right]
\end{gathered}
$$

where $\sigma_{R M S}$ is the root-mean-square roughness of the interface, $n_{1}$ and $n_{2}$ are the refractive indexes of the incident and transmitted sides of the interface respectively, $\varphi_{1}$ and $\varphi_{2}$ are the incident and outgoing angles of the light beam respectively, $N_{R}$ and $N_{T}$ are the power factors for $H_{R}$ and $H_{T}$, respectively, $\lambda$ is the optical wavelength, $c_{R}\left(\lambda, \sigma_{R M S}\right)$ and $c_{T}\left(\lambda, \sigma_{R M S}\right)$ are the correction functions that are introduced to make the equations applicable to the random morphologies present at the interfaces in thin-film solar cells [19].

The default parameters $H_{R}$ and $H_{T}$ used in this work to simulate the $\mathrm{ZnO} / \mathrm{Cu}_{2} \mathrm{O}$ solar cell interface are presented in Table 2 [14].

Table 2 - The default parameters of $H_{R}$ and $H_{T}$ used to simulate the $\mathrm{ZnO} / \mathrm{Cu}_{2} \mathrm{O}$ interface

\begin{tabular}{|l|l|l|l|}
\hline$C_{R}$ & $C_{T}$ & $N_{R}$ & $N_{T}$ \\
\hline 1 & 0.5 & 2.0 & 3.0 \\
\hline
\end{tabular}

Main simulation results in this study are the EQE and charge carrier generation rate profile as a function of $\sigma_{R M S}$ in the $\mathrm{ZnO} / \mathrm{Cu}_{2} \mathrm{O}$ interface under $\mathrm{AM} 1.5$.

\subsection{ZnO Bulk Defects}

Most of thin films are non-crystalline materials. Therefore we can assume that the polycrystalline or amorphous nature of these films give rise defects their lattices; which, will give rise to different types of energy levels in the band gap of the material $[20,21]$.

In amorphous semiconductors, the density of states (DOS) is composed of four bands: two tail bands (a donor-like valence band and an acceptor-like conduction band) and two deep level bands (one acceptor-like and the other donor-like). The firsts are modeled as decaying exponentials from the band edge, while the latter are modeled using a Gaussian distribution. The density is then given by:

$$
\begin{aligned}
& g(E)=G_{G A} \exp \left[-\left[\frac{E_{G A}-E}{\sigma_{A}}\right]^{2}\right]+ \\
& +G_{G D} \exp \left[-\left[\frac{E-E_{G D}}{\sigma_{D}}\right]^{2}\right]+G_{T A} \exp \left[\frac{E-E_{C}}{E_{A}}\right]+ \\
& +G_{T D} \exp \left[\frac{E_{V}-E}{E_{D}}\right]
\end{aligned}
$$


where $E_{V(C)}$ is the valence (conduction) band edge, $G_{T D(A)}\left(\mathrm{cm}^{-3} \mathrm{Ev}^{-1}\right)$ is the effective density at $E_{V(C)}, E_{D(A)}$ is the characteristic slope energy of the valence (conduction) band-tail states, $G_{G A(D)}\left(\mathrm{cm}^{-3} \mathrm{eV}^{-1}\right)$ is the total density, $\sigma_{D}\left(\sigma_{A}\right)$ is the standard deviation and $E_{G D(A)}$ is the peak energy of the Gaussian distribution. The subscripts $G$ and $T$ are for Gaussian and tail, respectively, while $A$ and $D$ are for acceptor and donor, respectively.

The parameters of the DOS used to simulate the $\mathrm{ZnO}$ bulk of the $\mathrm{ZnO} / \mathrm{Cu}_{2} \mathrm{O}$ solar cell are presented in Table 3.

Furthermore the default values of capture crosssections for majority and minority carriers are $1 \times 10^{-14}$ and $1 \times 10^{-16} \mathrm{~cm}^{2}$ respectively for all states [14].

Main simulation results are the EQE as a function of acceptor-like defects DOS in the $\mathrm{ZnO}$ bulk under AM1.5.

Table 3 - The parameters of the DOS used to simulate the $\mathrm{ZnO}$ bulk of the $\mathrm{ZnO} / \mathrm{Cu}_{2} \mathrm{O}$ solar cell.

\begin{tabular}{|l|l|}
\hline Parameter & Value \\
\hline $\begin{array}{l}\text { Standard deviation of the deep accep- } \\
\text { tors } \sigma_{A}(\mathrm{eV})\end{array}$ & $0.025[14]$ \\
\hline $\begin{array}{l}\text { Standard deviation of the deep donors } \\
\sigma_{D}(\mathrm{eV})\end{array}$ & $0.05[14]$ \\
\hline Peak energy of deep acceptors $E_{G A}(\mathrm{eV})$ & $1.5[22]$ \\
\hline Peak energy of deep donors $E_{G D}(\mathrm{eV})$ & $0.75[22]$ \\
\hline $\begin{array}{l}\text { Characteristic slope energy of the va- } \\
\text { lence band-tail states } E_{A}(\mathrm{eV})\end{array}$ & $0.1[14]$ \\
\hline $\begin{array}{l}\text { Characteristic slope energy of the con- } \\
\text { duction band-tail states } E_{D}(\mathrm{eV})\end{array}$ & $0.1[14]$ \\
\hline
\end{tabular}

\section{RESULTS AND DISCUSSION}

\subsection{Morphology Properties}

The surface morphological study from scanning electron microscope (SEM) was carried out to confirm the growth pattern and the crystal distribution. Fig. 2 shows a profile of the surface on a nanoscale of $\mathrm{ZnO}$ prepared by sol-gel spin coating method. The SEM image, which was evaluated at $1.47 \mathrm{~K} \times$ magnification with $50 \mu \mathrm{m}$ resolution, revealed a rough surface topography with small and average particle sizes with random structure includes rods, granules, slots and wormlike shapes. The image, also, shows the $\mathrm{ZnO}$ thin film crystallinity study by using the energy dispersive X-ray analysis (EDXA), which was generated by the incident electron beams. It was achieved to investigate the $\mathrm{ZnO}$ thin film composition and to determine the $\mathrm{ZnO}$ crystal phase and average grain size. EDXA pattern for sol-gel spin-coated $\mathrm{ZnO}$ thin film indicates a polycrystalline structure, with peaks revealed that it is, mainly, composed of zinc ( $\mathrm{Zn})$ and oxygen $(\mathrm{O})$ atoms. The diffraction pattern matches the $\mathrm{ZnO}$ hexagonal wurtzite structure, without any secondary phase impurities in the films.

\subsection{Optical Characterization of $\mathrm{ZnO}$ Thin Film}

Fig. 3 shows the optical transmittance $(T)$ and reflectance $(R)$ spectra as a function of wavelengths from $250 \mathrm{~nm}$ to $1000 \mathrm{~nm}$ for $\mathrm{ZnO}$ thin film. The material transmittance spectra are generally determined by the thickness, surface roughness, and absorption coefficient. The transmittance values of $\mathrm{ZnO}$ thin film, in the

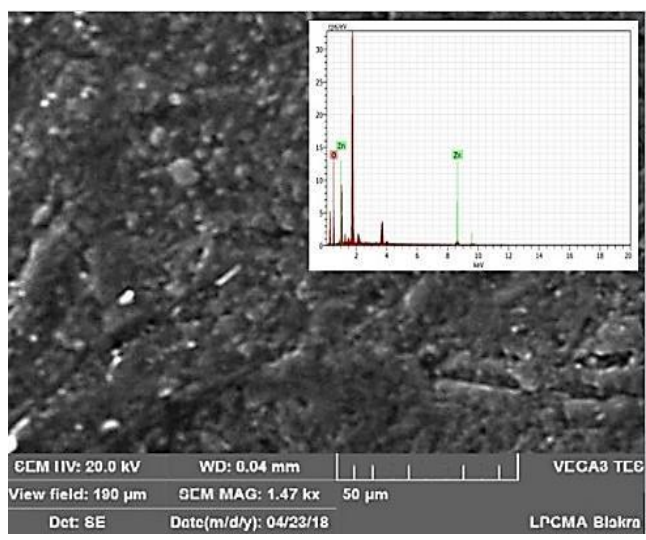

Fig. 2 - The SEM micrograph and EDXA of the ZnO thin film

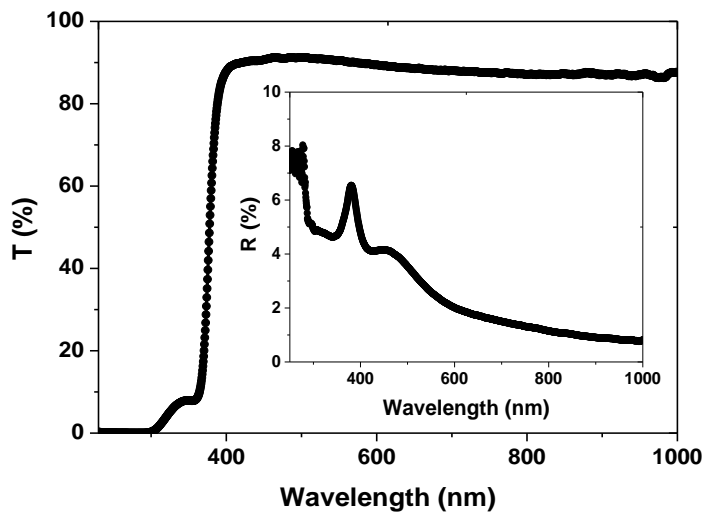

Fig. 3 - Optical transmittance $(T)$ and optical reflectance $(R)$ as function of wavelength

visible range, were found to be $T=87-91 \%$. The reflectance values of $\mathrm{ZnO}$ thin film decrease as the wavelengths increase, i.e. the energy decreases, in the range of $375 \mathrm{~nm}$ to $1000 \mathrm{~nm}$. High transmittance and low reflectance values in UV/VIS region of this film make it a suitable candidate as a TCO in solar cell applications. Considering that the interfaces are related to the thin film thickness in practical experiments, the transmittance and reflectance of the $\mathrm{ZnO}$-based materials obey the following equation [23]:

$$
T=(1-R)^{2} \exp [-\alpha d],
$$

where $d$ is the thickness of the thin film, $\alpha$ is the absorption coefficient. Thus, $\alpha$ can be calculated using the following equation:

$$
\alpha=-\frac{1}{d} \ln \left[T /(1-R)^{2}\right] .
$$

The optical bandgap $\left(E_{g}\right)$ value of the thin film was calculated from a plot using the absorption coefficient as shown in Fig. 4. The presence of a single slope in the plot suggests that the film has direct and allowed transition. The band gap energy is obtained by extrapolating the straight line portion of the plot to zero absorption coefficient. The band gap value of $\mathrm{ZnO}$ thin film is found to be $E_{g}=3.305 \mathrm{eV}$. The absorption coefficient of $\mathrm{ZnO}$ thin film is found to be neglected in forbidden energy region and it is found to increase rapidly with the decrease in wavelength beyond energy band gap. Ne- 
glected absorption coefficient values of $\mathrm{ZnO}$ thin film in the visible range of spectrum make it suitable as window layer in solar cells.

Fig. 5 shows the refractive index $(n)$ and extinction coefficient $(k)$, respectively, for the $\mathrm{ZnO}$ thin film prepared using the sol-gel spin-coating method. The knowledge of the dispersion of the refractive indices of any semiconductor materials is important to model and optimize, accurately, the optical properties. The complex refractive index of a semiconductor material can be expressed by [24]:

$$
\hat{n}=n(\omega)+i k(\omega),
$$

where $n$ and $k$ represent the real and imaginary parts respectively. The real part quantifies the phase velocity of light whereas the imaginary part quantifies the absorption of light in the material. The refractive index of a semiconductor material can be calculated using the following relation [25]:

$$
n=\left(\frac{1+R}{1-R}\right)+\sqrt{\frac{4 R}{(1-R)^{2}}-k^{2}},
$$

where $k=\alpha \lambda / 4 \pi$ is the extinction coefficient, which can be calculated from the optical transmittance of the material.

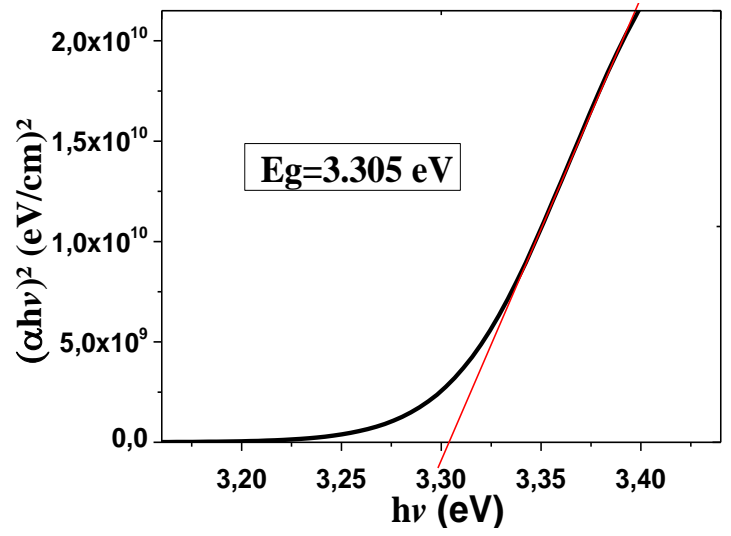

Fig. 4 - The optical band gap energy of the $\mathrm{ZnO}$ thin film

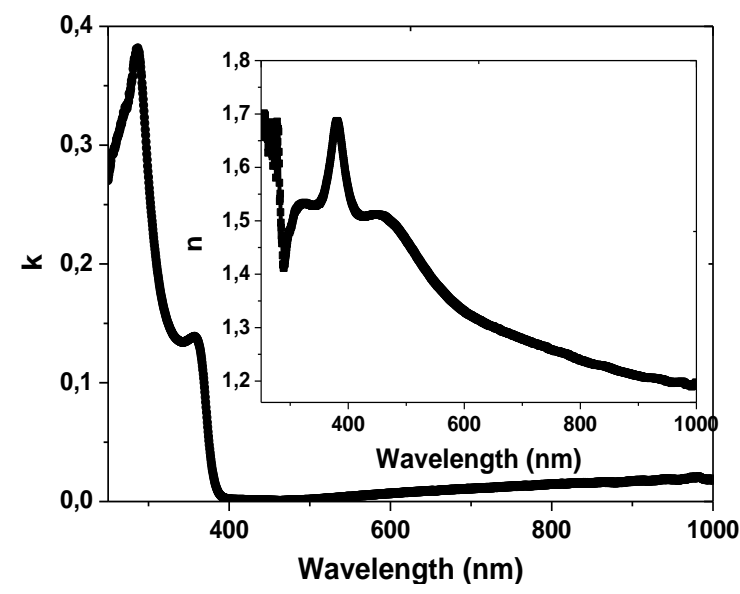

Fig. 5 - Refractive index $(n)$ and extinction coefficient $(k)$ as function of wavelength

\subsection{The Effect of the Root-mean-square Roughness of $\mathrm{ZnO} / \mathrm{Cu}_{2} \mathrm{O}$ Interface}

The root-mean-square roughness ( $\sigma R M S)$ values of the $\mathrm{ZnO} / \mathrm{Cu}_{2} \mathrm{O}$ interface under AM1.5 spectrum were varied from $40 \mathrm{~nm}$ to $80 \mathrm{~nm}$ while the defect density of states in the $\mathrm{ZnO}$ bulk kept constant at default values of an amorphous semiconductor [14]. The simulation results show that the $\sigma_{R M S}$ influences the EQE of the solar cell significantly as shown in Fig. 6. The increasing of the ORMS leads to higher average values of the EQE at wavelengths above $450 \mathrm{~nm}$, i.e. scattering of long wavelength light at higher oRMS is more efficient on the photon absorption which lead to an increase in the photogenerated carrier rate at the $\mathrm{ZnO} / \mathrm{Cu}_{2} \mathrm{O}$ interface as shown in Fig. 7 .

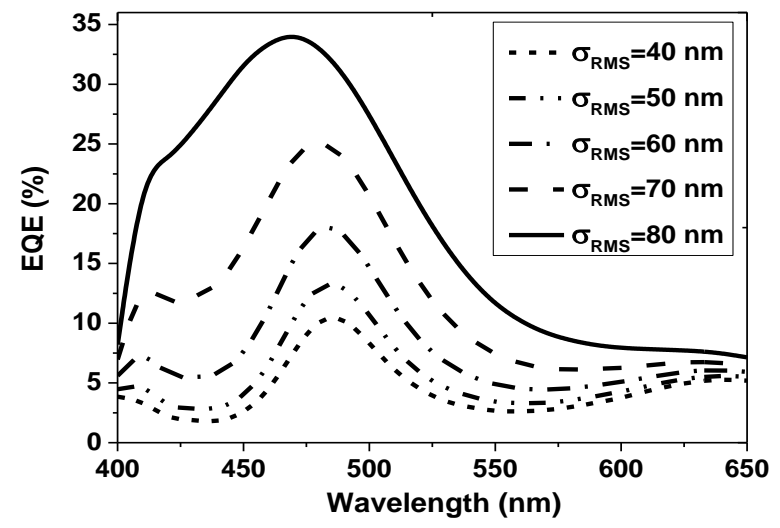

Fig. 6 - The External Quantum Efficiency (EQE) as function of wavelength for different values of root-mean-square roughness $\left(\sigma_{R M S}\right)$ in $\mathrm{ZnO} / \mathrm{Cu}_{2} \mathrm{O}$ interface

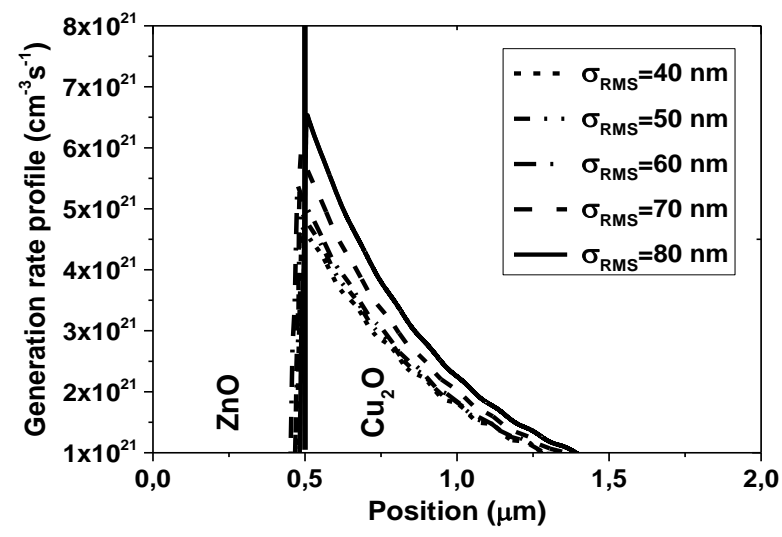

Fig. 7 - The generation rate profile at $\mathrm{ZnO} / \mathrm{Cu}_{2} \mathrm{O}$ interface for different values of root-mean-square roughness $\left(\sigma_{R M S}\right)$

\subsection{The Effect of Defects in $\mathrm{ZnO}$ Bulk}

Fig. 8 and Fig. 9 show the EQE as function of wavelengths for different values of defect density in $\mathrm{ZnO}$ bulk.

In the first case, we varied the defect density of tail states, $N_{T A}$, in $\mathrm{ZnO}$ bulk from $10^{18}$ to $1 \times 10^{22} \mathrm{~cm}^{-3}$, while the values of defect density with Gaussian distribution and $\sigma_{R M S}$ kept constants in $\mathrm{ZnO}$ bulk and $\mathrm{ZnO} / \mathrm{Cu}_{2} \mathrm{O}$ interface respectively. The cell performance is quite sensitive to the presence of defects of tail states in ZnO bulk. The density of defects higher than $10^{19} \mathrm{~cm}^{-3}$ produces a fall in the EQE as shown in Fig. 8. 


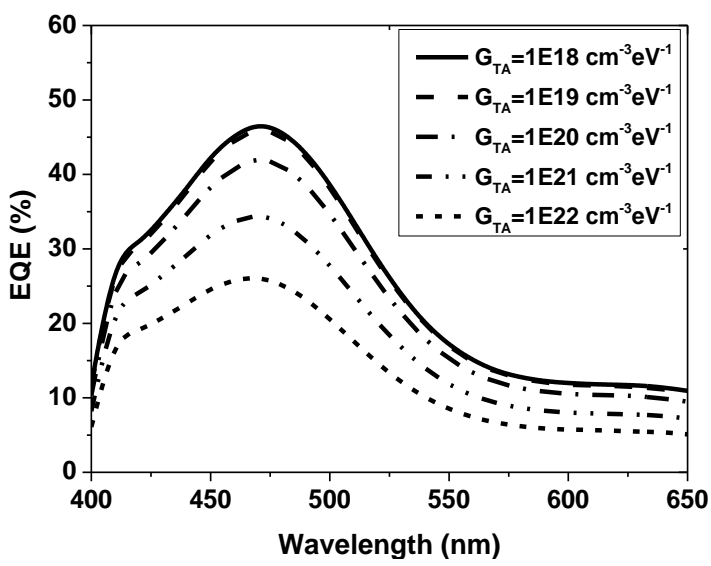

Fig. 8 - The External Quantum Efficiency (EQE) as function of wavelength for different values of the defect density of tail states $\left(N_{T A}\right)$ in $\mathrm{ZnO}$ bulk

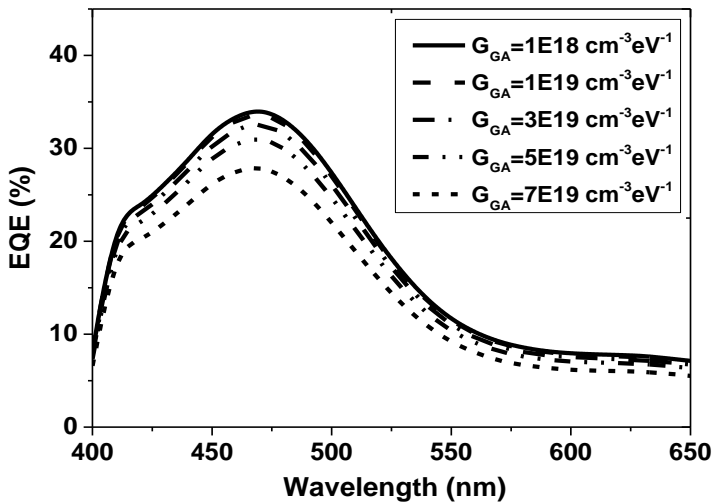

Fig. 9 - The External Quantum Efficiency (EQE) as function of wavelength for different values the defect density with Gaussian distribution $\left(N_{G A}\right)$ in $\mathrm{ZnO}$ bulk

The effect indicates that the defects act as dopants, modifying the doping profile and reducing the space charge zone of the junction. The decrease of $\mathrm{EQE}$ can be understood from the fact that the photogenerated carriers are captured by dense defects located near the conduction band.

In the second case, we varied the defect density with Gaussian distribution, $N_{G A}$, of $\mathrm{ZnO}$ bulk from $10^{18}$ to $7 \times 10^{19} \mathrm{~cm}^{-3}$, while the values of tail defects and $\sigma_{R M S}$ kept constant in $\mathrm{ZnO}$ bulk and $\mathrm{ZnO} / \mathrm{Cu}_{2} \mathrm{O}$ interface respectively. The cell performance is affected by the presence of defects in $\mathrm{ZnO}$ bulk. The density of defects higher than $10^{19} \mathrm{~cm}^{-3}$ produces a fall in the EQE as well as shown in Fig. 9.

The defects with Gaussian distribution located near the middle of the gap and thereby act as recombination centers where the increased density makes the recombination phenomena more significant and causes fewer photogenerate carriers and subsequently decreasing EQE.

\subsection{Comparison between Simulation and Measurements of EQE of $\mathrm{ZnO} / \mathrm{Cu}_{2} \mathrm{O}$ Solar Cell}

Simulation of the effect of root-mean-square interface roughness and the tail and Gaussian defect on the
$\mathrm{ZnO} / \mathrm{Cu}_{2} \mathrm{O}$ solar cell has led to comparable values between simulation and measurement for EQE. The comparison results were obtained with the following values: $\sigma_{R M S}=69 \mathrm{~nm}, \quad G_{T A}=3 \times 10^{21} \mathrm{~cm}^{-3} / \mathrm{eV}, \quad$ and $G_{G A}=1 \times 10^{19} \mathrm{~cm}^{-3} / \mathrm{eV}$. As it is very clear, there is a good agreement and the extracted parameters gave almost a perfect match between simulation and measurements as shown in Fig. 10.

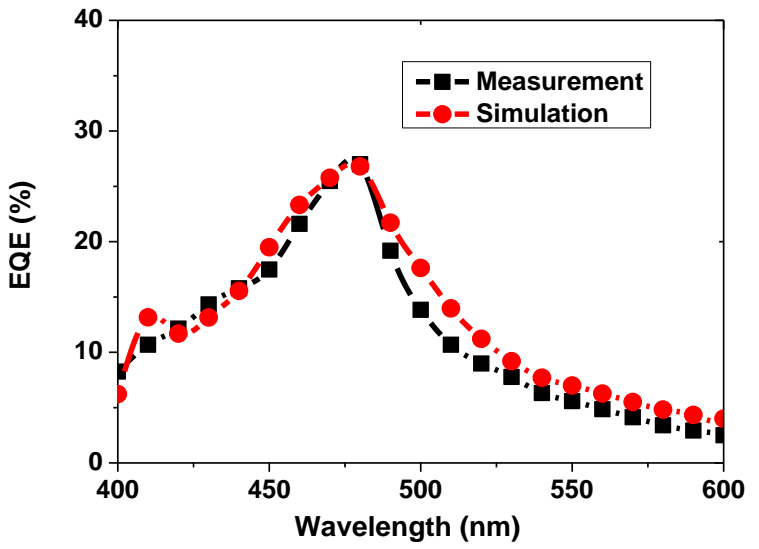

Fig. 10 - Comparison of simulated and measured EQE characteristics of the $\mathrm{ZnO} / \mathrm{Cu}_{2} \mathrm{O}$ solar cell

\section{CONCLUSIONS}

$\mathrm{ZnO}$ thin film was prepared by sol-gel spin-coating technique using zinc acetate precursor. The film was characterized by using optical measurements. The optical parameters, bandgap $\left(E_{g}\right)$, refractive index $(n)$ and extinction coefficient $(k)$ to be used in simulation were extracted from the optical transmittance and reflectance spectra.

$\mathrm{ZnO} / \mathrm{Cu}_{2} \mathrm{O}$ heterojunction solar cell, which was fabricated by sol-gel method using zinc acetate precursor, showed weak EQE compared to those fabricated by zinc nitrate and diethyl zinc. Numerical simulation using Silvaco ATLAS software was used to model the solar cell and to explain its weak EQE. Several possible cases were considered. In this work, the effect of root-meansquare roughness ( $\left.\sigma_{R M S}\right)$ of $\mathrm{ZnO} / \mathrm{Cu}_{2} \mathrm{O}$ interface, the presence of defects, tail $\left(G_{T A}\right)$ and Gaussian $\left(G_{G A}\right)$ states in the $\mathrm{ZnO}$ bulk were studied. As was supposed, these parameters were found to mainly affect the EQE of the solar cell. Good comparison between experimental and simulation results was obtained with these values: ORMS $=69 \mathrm{~nm}, \quad G_{T A}=3 \times 10^{21} \mathrm{~cm}^{-3} / \mathrm{eV}, \quad$ and $G_{G A}=1 \times 10^{19} \mathrm{~cm}^{-3} / \mathrm{eV}$. These values produced a good agreement in EQE study.

\section{ACKNOWLEDGEMENTS}

Slimane Chala would like to thank the Laboratory of Metallic and Semiconducting Materials (LMSM), University of Biskra, and the Algerian General Directorate of Scientific Research and Technological Development (DGRSDT) for their scientific and academic support. 


\section{REFERENCES}

1. T.S. Gershon, A.K. Sigdel, A.T. Marin, M.F.A.M. van Hest, D.S. Ginley, R.H. Friend, J.L. MacManus-Driscoll, J.J. Berry, Thin Solid Films 536, 280 (2013).

2. F. Yao, P. Sun, X. Sun, N. Huang, X. Ban, H. Huang, D. Wen, S. Liu, Y. Sun, Appl. Surf. Sci. 363, 459 (2016).

3. N. Spalatu, J. Hiie, N. Maticiuc, M. Krunks, A. Katerski, V. Mikli, I. Sildos, Appl. Surf. Sci. 350, 69 (2015).

4. S. Chala, N. Sengouga, F. Yakuphanoğlu, S. Rahmane, M. Bdirina, İ. Karteri, Energy 164, 871 (2018).

5. M. Elbar, S. Tobbeche, A. Merazga, Sol. Energ. 122, 104 (2015).

6. D.M. Bagnall, Y.F. Chen, Z. Zhu, T. Yao, S. Koyama, M.Y. Shen, T. Goto, Appl. Phys. Lett. 70, 2230 (1997).

7. H. Raebiger, S. Lany, A. Zunger, Phys. Rev. B 76, 045209 (2007).

8. C. Malerba, F. Biccari, C. Leonor, A. Ricardo, M.D. Incau, P. Scardi, A. Mittiga, Sol. Energ. Mater. Sol. C. 95, 2848 (2011).

9. T. Minami, Y. Nishi, T. Miyata, J. Nomoto, Appl. Phys. Exp. 4, 062301 (2011)

10. P.E. De Jongh, D. Vanmaekelbergh, J.J. Kelly, Chem. Mater. 11, 3512 (1999).

11. J. Cui, U.J. Gibson, J. Phys. Chem. C 114, 6408 (2010).

12. C.G. Morales-guio, S.D. Tilley, H. Vrubel, M. Grätzel, X. Hu, Nat Commun. 5, 3059 (2014).
13. M. Izaki, T. Shinagawa, K. Mizuno, Y. Ida, M. Inaba, A. Tasaka, J. Phys. D: Appl. Phys. 40, 3326 (2007).

14. Silvaco, Atlas User's Manual: Device Simulation Software (Silvaco, Inc, Santa Clara, USA, 2013).

15. Y. Takiguchi, S. Miyajima, Jpn. J. Appl. Phys. 54, 112303 (2015).

16. Y. Hwang, H. Ahn, M. Kang, Y. Um, Curr. Appl. Phys. 15, S89 (2015).

17. J.S. Ahn, R. Pode, K.B. Lee, Thin Solid Films 623, 121 (2017).

18. H.E. Bennett, J.O. Porteus, J. Opt. Soc. Am. 51, 123 (1961).

19. J. Krč, M. Zeman, F. Smole, M. Topič, J. Appl. Phys. 92, 749 (2002).

20. T.E. Taouririt, A. Meftah, N. Sengouga, M. Adaika, S. Chala, A. Meftah, Nanoscale 11, 23459 (2019).

21. S. Chala, N. Sengouga, F. Yakuphanoglu, Vacuum 120, 81 (2015).

22. J. Park, Y.S. Rim, C. Li, H. Kim, M. Goorsky, D. Streit, Curr. Appl. Phys. 16, 1369 (2016).

23. M.S. Kim, K.G. Yim, S. Kim, G. Nam, D.Y. Lee, J.S. Kim, J.S. Kim, J.Y. Leem, Acta Phys. Pol. A 121, 217 (2012).

24. F. Yakuphanoglu, A. Cukurovali, I. Yilmaz, Opt. Mater. 27, 1363 (2005).

25. M.R. Islam, J. Podder, Cryst. Res. Technol. 44, 286 (2009). 